\title{
Notulae to the Italian alien vascular flora: 3
}

Gabriele Galasso', Gianniantonio Domina ${ }^{2}$, Nicola M.G. Ardenghi ${ }^{3}$, Silvia Assini ${ }^{3}$, Enrico Banfi', Fabrizio Bartolucci ${ }^{4}$, Valentina Bigagli ${ }^{5}$, Gianmaria Bonari ${ }^{6}$, Emanuel Bonivento ${ }^{7}$, Paolo Cauzzi ${ }^{3}$, Francesco S. D’Amico ${ }^{8}$, Marco D’Antraccoli ${ }^{9}$, Daniela Dinelli ${ }^{10}$, Giulio Ferretti ${ }^{\prime \prime}$, Matilde Gennai ${ }^{\prime \prime}$, Gabriele Gheza ${ }^{3}$, Alessandro Guiggi ${ }^{12}$, Filippo Guzzon ${ }^{3}$, Duilio Iamonico ${ }^{13}$, Mauro Iberite ${ }^{14}$, Marta Latini ${ }^{14}$, Michele Lonati ${ }^{15}$, Giacomo Mei ${ }^{16}$, Gianluca Nicolella ${ }^{14}$, Nicola Olivieri ${ }^{17}$, Simonetta Peccenini ${ }^{12}$, Giacomo Peraldo ${ }^{18}$, Enrico V. Perrino ${ }^{19}$, Filippo Prosser ${ }^{20}$, Francesco Roma-Marzio9, Giovanni Russo ${ }^{21}$, Alberto Selvaggi22, Adriano Stinca ${ }^{23}$, Massimo Terzi ${ }^{24}$, Jean-Marc Tison ${ }^{25}$, Juri Vannini ${ }^{5}$, Filip Verloove ${ }^{26}$, Robert P. Wagensommer ${ }^{27}$, Thomas Wilhalm ${ }^{28}$, Chiara Nepi ${ }^{29}$

I Sezione di Botanica, Museo di Storia Naturale di Milano, Corso Venezia 55, 20121 Milano, Italy 2 Dipartimento di Scienze Agrarie e Forestali, Università di Palermo, Via Archirafi 38, 90123 Palermo, Italy 3 Dipartimento di Scienze della Terra e dell'Ambiente, Università di Pavia, Via Sant'Epifanio 14, 27100 Pavia, Italy 4 Scuola di Bioscienze e Medicina Veterinaria, Università di Camerino - Centro Ricerche Floristiche dell'Appennino, Parco Nazionale del Gran Sasso e Monti della Laga, San Colombo, 67021 Barisciano (L'Aquila), Italy 5 Dipartimento provinciale di Pistoia, Area vasta Centro, Agenzia Regionale per la Protezione Ambientale della Toscana, Via dei Baroni 18, 51100 Pistoia, Italy 6 Dipartimento di Scienze della Vita, Università di Siena, Via P.A. Mattioli 4, 53100 Siena, Italy 7 Via C. Cavour 11, 13845 Ronco Biellese (Biella), Italy 8 Museo Orto Botanico, Dipartimento di Biologia, Università di Bari, Via E. Orabona 4, 70126 Bari, Italy 9 Dipartimento di Biologia, Università di Pisa, Via Derna 1, 56126 Pisa, Italy 10 Unità operativa Biologia, Settore Laboratorio, Area vasta Centro, Agenzia Regionale per la Protezione Ambientale della Toscana, Via Ponte alle Mosse 211, 50144 Firenze, Italy I I Dipartimento di Biologia, Università di Firenze, Via G. La Pira 4, 50121 Firenze, Italy 12 Dipartimento di Scienze della Terra, dell'Ambiente e della Vita (DISTAV), Università di Genova, Corso Dogali 1/m, 16136 Genova, Italy 13 Dipartimento di Pianificazione, Design, Tecnologia dell'Architettura (PDTA), Sapienza Università di Roma, Via Flaminia 72, 00196 Roma, Italy 14 Dipartimento di Biologia Ambientale, Sapienza Università di Roma, Piazzale A. Moro 5, 00185 Roma, Italy 15 Dipartimento di Scienze Agrarie, Forestali e Alimentari, Università di Torino, Largo P. Braccini 1, 10095 Grugliasco (Torino), Italy 16 Sezione Botanica ed Ecologia, Dipartimento di Scienze Agrarie, Alimentari ed Ambientali, Università Politecnica delle Marche, Via Brecce Bianche 10, 60131 Ancona, Italy 17 Via Maestri del Lavoro 40, 64100 Teramo, Italy 18 Vicolo Molinaro 6, 13811 Andorno Micca (Biella), Italy 19 CIHEAM - Istituto Agronomico Mediterraneo di Bari, Via Ceglie 9, 70010 Valenzano (Bari), Italy 20 Fondazione Museo Civico di Rovereto, Largo Santa Caterina 41, 38068 Rovereto (Trento), Italy 2 I Via G. Ercolino Soldato 11, 71013

Copyright Gabriele Galasso et al. This is an open access article distributed under the terms of the Creative Commons Attribution License (CC BY 4.0), which permits unrestricted use, distribution, and reproduction in any medium, provided the original author and source are credited. 
San Giovanni Rotondo (Foggia), Italy 22 Istituto per le Piante da Legno e l'Ambiente (IPLA), Corso Casale 476, 10132 Torino, Italy 23 Dipartimento di Agraria, Università di Napoli Federico II, Via Università 100, 80055 Portici (Napoli), Italy 24 Istituto di Bioscienze e Biorisorse (IBBR), Consiglio Nazionale delle Ricerche (CNR), Via G. Amendola 165/a, 70126 Bari, Italy 25 Chemin du Valentier, 38540 Heyrieux, France 26 Botanic Garden of Meise, Nieuwelaan 38, 1860 Meise, Belgium 27 Dipartimento di Chimica, Biologia e Biotecnologie, Università di Perugia, Via Elce di Sotto 8, 06123 Perugia, Italy 28 Museo di Scienze Naturali dell'Alto Adige, Via dei Bottai 1, 39100 Bolzano, Italy 29 Sezione di Botanica Filippo Parlatore, Museo di Storia Naturale, Università di Firenze, Via G. La Pira 4, 50121 Firenze, Italy

Corresponding author: Gabriele Galasso (gabriele.galasso@comune.milano.it)

Academic editor: L. Peruzzi | Received 7 April 2017 | Accepted 26 April 2017 | Published 17 May 2017

Citation: Galasso G, Domina G, Ardenghi NMG, Assini S, Banfi E, Bartolucci F, Bigagli V, Bonari G, Bonivento E, Cauzzi P, D’Amico FS, D’Antraccoli M, Dinelli D, Ferretti G, Gennai M, Gheza G, Guiggi A, Guzzon F, Iamonico D, Iberite M, Latini M, Lonati M, Mei G, Nicolella G, Olivieri N, Peccenini S, Peraldo G, Perrino EV, Prosser F, RomaMarzio F, Russo G, Selvaggi A, Stinca A, Terzi M, Tison J-M, Vannini J, Verloove F, Wagensommer RP, Wilhalm T, Nepi C (2017) Notulae to the Italian alien vascular flora: 3. Italian Botanist 3: 49-71. doi: 10.3897/italianbotanist.3.13126

\begin{abstract}
In this contribution, new data concerning the Italian distribution of alien vascular flora are presented. It includes new records, exclusions, confirmations, and status changes for Italy or for Italian administrative regions for taxa in the genera Acer, Amaranthus, Araujia, Aubrieta, Avena, Bidens, Calycanthus, Celtis, Elaeagnus, Eragrostis, Euonymus, Fallopia, Ficus, Hedera, Lantana, Ligustrum, Ludwigia, Morus, Oenothera, Opuntia, Oxalis, Parkinsonia, Paspalum, Paulownia, Platycladus, Pleuropterus, Rumex, Salvia, Senecio, Setaria, Syagrus, Tradescantia, Trifolium and Yucca. Furthermore, a new combination in the genus Vicia is proposed.
\end{abstract}

\title{
Keywords
}

Floristic data, Italy, new combination

\section{How to contribute}

The text for the new records should be submitted electronically to Chiara Nepi (chiara.nepi@unifi.it). The corresponding specimen along with its scan or photograph has to be sent to FI Herbarium: Sezione di Botanica Filippo Parlatore del Museo di Storia Naturale, Via G. La Pira 4, 50121 Firenze (Italy). Those texts concerning nomenclatural novelties (typifications only for accepted names), status changes, exclusions, and confirmations should be submitted electronically to: Gabriele Galasso (gabriele.galasso@comune.milano.it). Each text should be within 2,000 characters (spaces included). 


\section{Floristic records}

\section{Acer negundo L. (Sapindaceae)}

+ (CAS) PUG: Maglie (Lecce), margine del parco pubblico "Villa Achille Tamborino" (WGS84: $40.117286^{\circ} \mathrm{N} ; 18.299727^{\circ} \mathrm{E}$ ), siepi e radure, ca. $82 \mathrm{~m}, 20$ August 2016, $N$. Olivieri (FI). - Casual alien species new for the flora of Puglia.

Several young individuals of the species, some higher than $2 \mathrm{~m}$, grow at the margins of an urban park, inside hedges of Laurus nobilis L. and in clearings of Quercus ilex L. subsp. ilex. The specimens have developed in a partially shaded position, on dry, brown, calcareous luvisol covered by evergreen oak litter. They derive from winddispersed samaras produced by trees cultivated in the park.

N. Olivieri

\section{Amaranthus ×ozanonii Thell. (Amaranthaceae)}

+ (CAS) CAL: Oriolo (Cosenza), C.da Scalapitta nei pressi del Torrente Scalapitto (WGS84: $40.040365^{\circ} \mathrm{N} ; 16.451603^{\circ} \mathrm{E}$ ), incolto al margine di una strada sterrata, 325 m, 24 August 2016, F. Roma-Marzio (FI). - Casual alien nothospecies new for the flora of Calabria.

This hybrid between Amaranthus hybridus L. and A. retroflexus L. is probably native to Europe (Iamonico 2015). In Oriolo it is represented by many plants occupying uncultivated land at the margin of a dirt road.

F. Roma-Marzio, D. Iamonico

\section{Araujia sericifera Brot. (Apocynaceae)}

+ (CAS) MOL: Termoli (Campobasso), versante collinare $S$ del Vallone del Riovivo (WGS84: $41.994961^{\circ} \mathrm{N} ; 14.995788^{\circ} \mathrm{E}$ ), pineta artificiale, ca. $27 \mathrm{~m}, 3$ September 2016, N. Olivieri (FI). - Casual alien species new for the flora of Molise.

The species is represented by a small number of individuals in the undergrowth of an artificial pine forest composed mostly of Pinus halepensis Mill. subsp. halepensis and P. pinaster Aiton subsp. escarena (Risso) K.Richt., in the urban park of Termoli near the Adriatic coast. Plants grow in partial shade, on sandstone soil covered by a herbaceous vegetation typical of disturbed areas.

N. Olivieri 


\section{Aubrieta deltoidea (L.) DC. (Brassicaceae)}

$=$ Aubrieta $\times$ cultorum Bergmans

+ (CAS) TAA: Pieve Tesino (Trento), walls of the town centre (WGS84: $46.069459^{\circ} \mathrm{N}$; $11.609140^{\circ} \mathrm{E}$ ), stone and cement walls, $850 \mathrm{~m}, \mathrm{~S}, 27$ June 2016, G. Mei (FI, ANC, Herb. G. Mei). - Casual alien species new for the flora of Trentino-Alto Adige.

The species is widely cultivated as ornamental and is naturalized in southern and western Europe, widespread in Spain, France, Switzerland, England, Greece and the Balkans. The population of Pieve Tesino is interesting for its abundant fructification, for the presence of individuals of different ages and for the presence of seedlings. These features can be interpreted as the possible start of a future naturalization of the species.

G. Mei

\section{Avena atherantha C.Presl (Poaceae)}

+ (NAT) MAR: Potenza Picena (Macerata), Autostrada "Adriatica" A14, a S di C.da Terranova (WGS84: $43.384741^{\circ} \mathrm{N} ; 13.680887^{\circ} \mathrm{E}$ ), scarpata stradale, con Sambucus ebulus, Arundo donax, Urtica dioica, 8 m, 30 May 2016, N. Ardenghi, P. Cauzzi, F. Guzzon (FI). - Naturalized cryptogenic species confirmed for the flora of Marche.

A large population was detected growing on the motorway embankment; further stands (impossible to sample due to their unsafe location) were observed along Autostrada A14 in the same area. The species was first reported for this region by Ballelli (2002), but the record was not taken into account by Gubellini $(2005,2009)$.

N.M.G. Ardenghi, P. Cauzzi, F. Guzzon

\section{Avena sativa L. subsp. byzantina (K.Koch) Romero Zarco (Poaceae)}

+ (CAS) BAS: Matera (Matera), tra Masseria di Pietrapenta e Strada Provinciale Papalione (WGS84: $40.631968^{\circ} \mathrm{N} ; 16.545906^{\circ} \mathrm{E}$ ), margine di sterrata, con Avena barbata e Dasypyrum villosum, 150 m, 9 June 2016, N. Ardenghi, P. Cauzzi (FI). - Casual alien species new for the flora of Basilicata.

About 100 individuals were observed on the edges of an unsurfaced road.

N.M.G. Ardenghi, P. Cauzzi, F. Guzzon 


\section{Bidens aurea (Aiton) Sherff (Asteraceae)}

+ (NAT) PUG: San Nicandro Garganico (Foggia), presso San Giuseppe (Km 20 della Strada Provinciale) (WGS84: $\left.41.823250^{\circ} \mathrm{N} ; 15.549489^{\circ} \mathrm{E}\right)$, cunette stradali, $250 \mathrm{~m}$, 6 December 1987, F. Pantaleo (RO-Anzalone-3688); ibidem, presso "San Giuseppe" (WGS84: $41.823250^{\circ} \mathrm{N} ; 15.549489^{\circ} \mathrm{E}$ ), cunette stradali, $250 \mathrm{~m}, 23$ November 1988, F. Pantaleo (RO-Anzalone-3689 sub Bidens sp.); ibidem, a W del paese, all'inizio della strada per San Marco in Lamis (WGS84: $41.823250^{\circ} \mathrm{N} ; 15.549489^{\circ} \mathrm{E}$ ), cunetta stradale, 250 m, 27 October 2016, R.P. Wagensommer (FI, Herb. R.P. Wagensommer). - Naturalized alien species new for the flora of Puglia.

In Italy, Bidens aurea is already known in Veneto, Toscana, Sicilia (Conti et al. 2005, 2007), Calabria (Bernardo et al. 2009), Lazio (Ceschin et al. 2010), Campania (Rosati et al. 2012), and Sardegna (Podda et al. 2012). During the digitization of the B. Anzalone herbarium in RO (Iberite et al. 2010), we found sheets collected almost 30 years ago in Puglia, on the Gargano Promontory, near San Nicandro Garganico. A field trip allowed us to confirm that the species is still present in the same locality, covering a small area of about $5 \mathrm{~m}^{2}$, with no evidence of invasiveness.

G. Nicolella, M. Latini, R.P. Wagensommer, M. Iberite

\section{Calycanthus floridus L. (Calycanthaceae)}

+ (CAS) ITALIA (TOS): Seravezza (Lucca), valle del Torrente Serra, lungo la strada per Azzano, poco dopo la loc. Desiata (WGS84: $44.025840^{\circ} \mathrm{N} ; 10.221460^{\circ} \mathrm{E}$ ), casuale lungo la scarpata stradale, 216 m, 8 June 2016, G. Ferretti, M. Gennai, det. G. Ferretti (FI). - Casual alien species new for the flora of Italy (Toscana).

Calycanthus floridus is native to North America and cultivated in Italy as ornamental. A spontaneous population on an area of approximately $50 \mathrm{~m}^{2}$ was found on the way to Azzano on the Apuan Alps, on a slope at the road edge. The population is probably originated from a plant once cultivated nearby. The specimens were identified according to Johnson (1997).

G. Ferretti, M. Gennai

\section{Celtis occidentalis L. (Cannabaceae)}

+ (CAS) ABR: Teramo (Teramo), loc. Coste di Sant'Agostino, lungo Via A. De Gasperi (WGS84: $42.663697^{\circ} \mathrm{N}$; $13.703552^{\circ} \mathrm{E}$ ), margine stradale, ca. $270 \mathrm{~m}, \mathrm{SW}, 27$ August 2016, N. Olivieri (FI). - Casual alien species new for the flora of Abruzzo. 
A young individual, about $2 \mathrm{~m}$ high, grows at the road edge, along the northern side of the Vezzola River valley covered by disturbed shrub vegetation. The location is outside the urban area and is characterized by pelitic-arenaceous sedimentary substrate. The vegetation consists of Robinia pseudoacacia L., Rubus ulmifolius Schott, Ailanthus altissima (Mill.) Swingle, Hedera helix L. Ulmus minor Mill., Artemisia verlotiorum Lamotte and Inula conyzae (Griess.) DC. There are no trees of C. occidentalis nearby, so the plant could be derived from a seed dispersed by endozoochory, since its fleshy drupes are eaten by birds. Until now the species has been reported in Italy from Piemonte, Lombardia, Veneto, Trentino-Alto Adige (Celesti-Grapow et al. 2009), and Emilia-Romagna (Bracchi and Romani 2010).

N. Olivieri

\section{Elaeagnus ×ebbingei Door. (Elaeagnaceae)}

+ (CAS) ITALIA (ABR): Pescara (Pescara), "Pineta Dannunziana" (WGS84: $\left.42.455813^{\circ} \mathrm{N} ; 14.234277^{\circ} \mathrm{E}\right)$, radure, ca. $2 \mathrm{~m}, 11$ August 2016, N. Olivieri (FI). Casual alien nothospecies new for the flora of Italy (Abruzzo).

Elaeagnus $\times$ ebbingei (E. macrophylla Thunb. $\times$ E. pungens Thunb.) is a hybrid used as an ornamental plant, especially in coastal areas. Some individuals grow on dry sandy substrates in peripheral clearings of the "Pineta Dannunziana", near the Adriatic Sea not far from private and public gardens where the plant might be cultivated. They are partially shaded by foliage of Pinus halepensis Mill. subsp. halepensis. The presence of E. xebbingei in Italy has also been reported in Emilia-Romagna, but only as cultivated hybrid in pinewoods and dunes of the Parco Delta del Po (Lazzari et al. 2010, 2012). The species was identified according to Barnes and Whiteley (2011).

N. Olivieri

\section{Eragrostis curvula (Schrad.) Nees (Poaceae)}

- LOM. - Alien species to be excluded from the flora of Lombardia.

The only record of Eragrostis curvula for Lombardia (Mauri et al. 2012), based on a herbarium specimen stored at MSNM (duplicate in FI), is actually a misidentification with E. pectinacea (Michx.). 
Eragrostis mexicana (Hornem.) Link subsp. virescens (J.Presl) S.D.Koch \& Sánchez Vega (Poaceae)

+ (CAS) PUG: Casamassima (Bari) (WGS84: $\left.40.951816^{\circ} \mathrm{N} ; 16.888951^{\circ} \mathrm{E}\right)$, campo di olivi e altri fruttiferi, periodicamente arato, $230 \mathrm{~m}, 27$ September 2016, F.S. D'Amico, M. Terzi (FI, BI). - Casual alien species new for the flora of Puglia.

Eragrostis mexicana subsp. virescens is an alien plant from South America (Argentina and Chile) whose European distribution area ranges from Portugal to Poland, and from Great Britain to Italy (Martini and Scholz 1998, Valdés and Scholz 2009). In Italy, it was recorded in northern regions and Calabria (Martini and Scholz 1998, Celesti-Grapow et al. 2009, Galasso et al. 2016a). A few individuals were found in an olive grove in a typical weed vegetation, thus confirming the occurrence of this taxon in southern Italy, where it has probably been confused with E. pilosa (L.) P.Beauv. subsp. pilosa, from which it can be distinguished for the lower isolated branch of the inflorescence (versus verticillate) and a pit on the ventral face of seeds (Martini and Scholz 1998).

F.S. D’Amico, M. Terzi

\section{Euonymus japonicus Thunb. (Celastraceae)}

+ (CAS) PUG: Otranto (Lecce), ruderi di un edificio situato in Via M. Corti (WGS84: $\left.40.152152^{\circ} \mathrm{N} ; 18.473799^{\circ} \mathrm{E}\right)$, ruderi, ca. $7 \mathrm{~m}, 21$ August 2016, N. Olivieri (FI). Casual alien species new for the flora of Puglia.

An individual of the species, reaching $3 \mathrm{~m}$ in height, was found growing among limestone blocks within the ruins of a building collapsed some time ago. The plant grows in a rather shady position, protected from the wind, set against an inner wall of the building. The substrate is limestone rock debris and calcarenite, on which a layer of soil has developed. The site is characterized by a humid microclimate, a few meters away from the Adriatic Sea.

N. Olivieri

\section{Fallopia baldschuanica (Regel) Holub (Polygonaceae)}

+ (NAT) BAS: Matera (Matera), Tre Ponti, Strada Statale 7 “Appia”, all'altezza dell'ex "Bar Ristorante delle Murge" (WGS84: $40.679654^{\circ} \mathrm{N} ; 16.625529^{\circ} \mathrm{E}$ ), scarpata stradale, con Elymus cfr. repens, $351 \mathrm{~m}, \mathrm{~N}, 8$ June 2016, N. Ardenghi, P. Cauzzi, F. Guzzon (FI). - Naturalized alien species new for the flora of Basilicata.

Dense mats of this species have been observed also in Matera, about 350 m west from the locality of the reported herbarium specimen, along Strada Statale 7 (WGS84: 
$\left.40.679810^{\circ} \mathrm{N} ; 16.621462^{\circ} \mathrm{E}\right)$, and in Via V. Cappelluti, growing on an old wall (WGS84: $40.663492^{\circ} \mathrm{N} ; 16.599205^{\circ} \mathrm{E}$ ).

N.M.G. Ardenghi, P. Cauzzi, F. Guzzon

\section{Ficus microcarpa L.f. (Moraceae)}

+ (CAS) PUG: Brindisi (Brindisi), Via Duca degli Abruzzi, giardini pubblici presso il monumento al Marinaio d'Italia (WGS84: $40.645208^{\circ} \mathrm{N}$; $17.946816^{\circ} \mathrm{E}$ ), epifita su Phoenix canariensis, ca. 10 m, 22 August 2016, N. Olivieri (FI). - Casual alien species new for the flora of Puglia.

Ficus microcarpa is a halophytic species native to India, Sri Lanka, Nepal, China, Taiwan, Japan, Ryukyu Islands, Indochinese Peninsula, Indo-Malay Archipelago, Philippines, north-eastern Australia, New Caledonia, Solomon Islands, and part of Micronesia, widespread for ornamental purposes in Central and South America, Florida, southern California, Puerto Rico, Hawaiian Islands, Bermuda, New Zealand, and some Mediterranean countries. In many of these countries it is naturalized as lithophyte and hemi-epiphyte, often as invasive. In the Mediterranean region, it is considered invasive in Israel (Dufour-Dror 2013). In Brindisi, some young individuals have developed on the top of the trunk of a medium sized Phoenix canariensis H.Wildpret, between the rachis residues of cut leaves. They originated from seeds produced by a tree growing in a neighbouring garden. The syconia of this species are eaten by birds and the plant spreads by zoochory. In Italy, F. microcarpa has, until now, been reported in Sicilia (Schicchi 1999, Domina and Mazzola 2002) and Sardegna (Lazzeri et al. 2015) as naturalized and casual alien species, respectively.

N. Olivieri

\section{Hedera algeriensis Hibberd (Araliaceae)}

+ (CAS) MAR: Grottammare (Ascoli Piceno), Via Beata L. Sernardi (WGS84: $\left.42.996095^{\circ} \mathrm{N} ; 13.866046^{\circ} \mathrm{E}\right)$, crepa nell'asfalto tra muro e strada, $91 \mathrm{~m}, 30$ May 2016, N. Ardenghi, P. Cauzzi, F. Guzzon (FI). - Casual alien species new for the flora of Marche.

N.M.G. Ardenghi, P. Cauzzi, F. Guzzon

\section{Hedera canariensis Willd. (Araliaceae)}

+ (CAS) PUG: Bisceglie (Barletta-Andria-Trani), loc. Matinella, SP85 (WGS84: $\left.41.186373^{\circ} \mathrm{N} ; 16.472764^{\circ} \mathrm{E}\right)$, incolto con Lolium perenne e Vitis $\times$ koberi, $120 \mathrm{~m}$, 
2 June 2016, N. Ardenghi, P. Cauzzi, F. Guzzon (FI). - Casual alien species new for the flora of Puglia.

N.M.G. Ardenghi, P. Cauzzi, F. Guzzon

\section{Lantana camara L. subsp. aculeata (L.) R.W.Sanders (Verbenaceae)}

+ (NAT) SIC: Palermo (Palermo), Inserra (WGS84: $38.151857^{\circ} \mathrm{N} ; 13.305263^{\circ} \mathrm{E}$ ), pascolo, ca. 150 m, 9 November 2001, P. Mazzola, G. Domina (PAL); Vittoria (Ragusa), Scoglitti, incolti a E di Via Cocalo (WGS84: $36.889971^{\circ} \mathrm{N}$; $14.436246^{\circ} \mathrm{E}$ ), incolto con Mirabilis jalapa, Saccharum biflorum e Solanum linnaeanum, $31 \mathrm{~m}$, no exp., 10 June 2014, E. Banfi (FI, MSNM); Santa Flavia (Palermo), Capo Zafferano, sulle pareti delle rupi sopra la strada (Stradella Vicinale Torre Zafferano) che porta al faro (WGS84: $38.110155^{\circ} \mathrm{N} ; 13.538511^{\circ} \mathrm{E}$ ), rupi, ca. $30 \mathrm{~m}$, NE, 16 June 2016, $G$. Domina (PAL). - Naturalized alien subspecies new for the flora of Sicilia.

This taxon has already been reported in Abruzzo (Galasso et al. 2016a) and Molise (Galasso et al. 2016b). The previous report for Sicilia by Domina and Mazzola (2002) of Lantana camara has to be referred to this subspecies. According to Sanders (2012), it is easily distinguished due to the stout, recurved, often abundant prickles that cover stems. The plant appears as a robust shrub sometimes up to $3 \mathrm{~m}$ in height; corollas, basically yellow, aging red-orange, are typically infused with purple, sometimes pink at opening, aging to deep reddish-purple. Cultivated worldwide in the tropics and subtropics (horticultural origin) and largely escaped, especially in Africa and Australia (Sanders 2012); within the genus Lantana, this taxon seems to show a great autonomy in temperate climates.

E. Banfi, G. Galasso, G. Domina

\section{Lantana depressa Small (Verbenaceae)}

+ (CAS) ITALIA (SIC): Vittoria (Ragusa), Scoglitti, prolungamento sterrato di Via Pescara verso la spiaggia (WGS84: $36.892863^{\circ} \mathrm{N} ; 14.427918^{\circ} \mathrm{E}$ ), residui di duna, $9 \mathrm{~m}$, no exp., 10 June 2014, E. Banfi (FI, MSNM). - Casual alien species new for the flora of Italy (Sicilia).

According to Sanders (2012), the collected plants have to be attributed to the type variety of the species (var. depressa) because of its low-mounded shape, the height not reaching $1 \mathrm{~m}$, the lack of a main stem, stems numerous, condensed, prominent, prostrate or decumbent and leaf blade not longer than $3 \mathrm{~cm}$, strigilloso-strigose on the adaxial surface. It comes from peninsular Florida (Miami Ridge), where it typically grows in limestone pinelands; extensively cultivated and escaped in tropics and subtropics worldwide (Sanders 2012). 


\section{Ligustrum sinense Lour. (Oleaceae)}

+ (CAS) MOL: Termoli (Campobasso), versante settentrionale del Vallone del Riovivo (WGS84: $41.996544^{\circ} \mathrm{N} ; 14.994824^{\circ} \mathrm{E}$ ), su lettiera di leccio, ca. $25 \mathrm{~m}, 3$ September 2016, N. Olivieri (FI). - Casual alien species new for the flora of Molise.

Some young individuals grow on sandy soil, rich in litter, in the urban park of Termoli, under some Quercus ilex L. subsp. ilex trees and together with young plants of Rhamnus alaternus L. subsp. alaternus and Q. ilex. They have originated from seeds produced by some plants cultivated in the park.

N. Olivieri

Ludwigia peploides (Kunth) P.H.Raven subsp. montevidensis (Spreng.) P.H.Raven (Onagraceae)

+ (INV) TOS: Carmignano (Prato), fraz. Comeana, sponda del Torrente Ombrone Pistoiese (WGS84: $43.790174^{\circ} \mathrm{N} ; 11.058680^{\circ} \mathrm{E}$ ), sponda, popolazione di alcuni metri quadrati, distribuita sia in destra che in sinistra idrografica, $32 \mathrm{~m}, 26$ August 2016, J. Vannini, D. Dinelli, det. J. Vannini, D. Dinelli, V. Bigagli (FI). - Invasive alien subspecies new for the flora of Toscana.

Ludwigia peploides subsp. montevidensis is an aquatic subspecies of South American origin, established in many European countries. It was introduced in Italy in the $20^{\text {th }}$ century as ornamental plant for aquaria (Banfi and Galasso 2010). It quickly spread in many regions of northern Italy, as well as in Lazio (Azzella and Iberite 2010). It is a harmful invasive plant due to its rapid vegetative growth and high spread potential. The plant is subject to control and eradication projects in many European and South American countries. It was recently included in the list of Invasive Alien Species of Union Concern (Commission Implementing Regulation EU 2016/1141). The plant was identified according to Galasso (2007) and it was also observed in other locations along the Torrente Ombrone (il Castellare -Pistoia municipality, Pistoia-, Caserana and Ferruccia-Quarrata municipality, Pistoia-) and along the Arno River (Camaioni -Montelupo Fiorentino municipality, Firenze-). During the summer of 2016, rapid expansion of the taxon and a considerable increase of its coverage was observed.

J. Vannini, D. Dinelli, V. Bigagli, G. Ferretti

\section{Morus indica L. (Moraceae)}

+ (CAS) ABR: Francavilla al Mare (Chieti), recinzione in cemento posta tra un parcheggio e la linea ferroviaria, presso Via C. de Titta (WGS84: $42.421338^{\circ} \mathrm{N} ; 14.287327^{\circ} \mathrm{E}$ ), bordo di recinzione, ca. 3 m, 28 October 2016, N. Olivieri (FI). - Casual alien species new for the flora of Abruzzo. 
A young specimen, about $2 \mathrm{~m}$ tall, grows within the town, on sandy soil near the Adriatic coast. The species is present with some adult trees grown as ornamental in neighboring private gardens. Morus indica is an East Asian species, originally distributed in China, Japan, Korea, Bhutan, India, Myanmar and Nepal (Zhou and Gilbert 2003), which has recently spread in Mediterranean countries as ornamental and shadetree species, especially in coastal areas, for its resistance to salty winds. In Italy, $M$. indica had been found, so far, only in Lazio (Galasso et al. 2016b).

N. Olivieri

+ (CAS) PUG: Gallipoli (Lecce), lungo Via Messina, in un'area parzialmente ombreggiata (WGS84: 40.060313이 $17.998421^{\circ} \mathrm{E}$ ), bordo di marciapiede, ca. $27 \mathrm{~m}, 19$ August 2016, N. Olivieri (FI). - Casual alien species new for the flora of Puglia.

A young individual was found growing along the sidewalk in an area, partially shaded by the foliage of Grevillea robusta A.Cunn. ex R.Br., near a public garden where there is an arboreal individual of the species. The place is located in a suburban area, not far from the Ionian Sea.

N. Olivieri

\section{Oenothera laciniata Hill. (Onagraceae)}

+ (CAS) LOM: Vigevano (Pavia), Bosco Ronchi (WGS84: $45.285492^{\circ} \mathrm{N} ; 8.937638^{\circ} \mathrm{E}$ ), in a dry grassland, 75 m, 7 June 2016, G. Gheza, det. S. Assini (FI). - Casual alien species new for the flora of Lombardia.

Oenothera laciniata, which is native to North America, is known in Italy for Piemonte (Bouvet et al. 2005), Toscana (Foggi et al. 2005, Pierini and Peruzzi 2014) and Campania (Ricciardi et al. 1988). In the locality reported here, the species was recorded in a dry grassland of the Thero-Airion Tx. ex Oberd. 1957 in the valley of the Ticino River.

G. Gheza, S. Assini

\section{Opuntia polyacantha Haw. (Cactaceae)}

+ (CAS) ITALIA (TAA): Merano (Bolzano), Passeggiata Tappeiner (WGS84: $46.682944 \mathrm{~N} ; 11.154278^{\circ} \mathrm{E}$ ), prateria arida (Festucetalia valesiacae) su gneiss, $390 \mathrm{~m}$, 2 January 2016, T. Wilhalm (BOZ); ibidem, 30 June 2016, T. Wilhalm, A. Guiggi, $M$. Fink (FI, BOZ, HMGBH). - Casual alien species new for the flora of Italy (TrentinoAlto Adige).

Thise species, of North American origin, is characterized by a prostrate habit and brown-yellowish fruit, dry when ripe (Benson 1982). Rarely cultivated, it has a re- 
markable hardiness for low temperatures and showy blooms. The group of individuals observed in an area of ca. 1-2 $\mathrm{m}^{2}$, excluding the ornithochory for the characteristics of the fruit, is probably of anthropic origin due to the ornamental value of the species. The plant produces flowers and fruits in this habitat.

A. Guiggi, T. Wilhalm

\section{Oxalis latifolia Kunth (Oxalidaceae)}

+ (CAS) PUG: Foggia (Foggia), Villa Comunale - Parco Karol Wojtyla (WGS84: $41.462011^{\circ} \mathrm{N}$; $15.560057^{\circ} \mathrm{E}$ ), vegetazione erbacea al di sotto di esemplari di Pinus halepensis ed Eucalyptus camaldulensis, ca. 64 m, 18 August 2016, N. Olivieri (FI). Casual alien species new for the flora of Puglia.

The species occurs in several areas of the park, mostly partially shaded by trees and in flowerbeds. Specimens have settled in groups on calcareous, alluvial, vertisol, in a dry area of herbaceous vegetation subjected to partial desiccation in the summer.

N. Olivieri

\section{Parkinsonia aculeata L. (Fabaceae)}

+ (CAS) LIG: Genova (Genova), Quinto al Mare, Via A. Gianelli $\left(44.383852^{\circ} \mathrm{N}\right.$; $9.022160^{\circ} \mathrm{E}$ ), fra la strada asfaltata e il marciapiede, $16 \mathrm{~m}, 22$ September 2016, S. Peccenini (FI). - Casual alien species new for the flora of Liguria.

Parkinsonia aculeata, native to the northern and central American deserts, is reported in Italy as naturalized in Sicilia and Puglia, casual in Lazio, Calabria and Sardegna (Celesti-Grapow et al. 2009, Celesti-Grapow et al. 2013, Buono et al. 2017).

S. Peccenini

\section{Paspalum dilatatum Poir. (Poaceae)}

+ (NAT) PIE: Ronco Biellese (Biella), fraz. San Carlo-Caucino, lungo i margini di Via Camillo Benso Conte di Cavour e nei prati immediatamente a ridosso della strada (WGS84: $45.5835^{\circ} \mathrm{N} ; 8.0852^{\circ} \mathrm{E}$ ), margine stradale e prati, $540 \mathrm{~m}, 25$ August 2015, G. Peraldo, E. Bonivento, conf. M. Lonati, A. Selvaggi, F. Verloove (FI). - Naturalized alien species new for the flora of Piemonte.

The genus Paspalum L. includes nearly 350 species distributed in tropical and subtropical regions, among which ten species are naturalized in Europe (Banfi and Galasso 2015, Verloove et al. 2016, Galasso et al. 2016a). In Italy, P. dilatatum was first ob- 
served in Liguria, where it probably started spreading after 1909 from the neighbouring Nice in France (Ariello 1952). Until recently, the species was known from most of the Italian administrative regions (Conti et al. 2005), but not yet from Piemonte. The vector of introduction in the San Carlo-Caucino locality is not clear. However, the species was probably introduced as a weed seed contained in chicken feed, as confirmed by the first plants being observed within a small family-run henhouse (year 2014). The species has been slowly spreading and now it occupies a scattered area close to the road, ranging between 520 to $550 \mathrm{~m}$ a.s.l.

G. Peraldo, E. Bonivento, M. Lonati, F. Verloove, A. Selvaggi

\section{Paulownia tomentosa (Thunb.) Steud. (Paulowniaceae)}

+ (CAS) PUG: Gallipoli (Lecce), bordo di giardino pubblico presso Via Pavia (WGS84: $\left.40.059127^{\circ} \mathrm{N} ; 17.997769^{\circ} \mathrm{E}\right)$, margine, ca. $27 \mathrm{~m}, 19$ August 2016, N. Olivieri (FI). Casual alien species new for the flora of Puglia.

The species is present with few, young individuals, some higher than $2 \mathrm{~m}$, growing on the edge of a public garden in a dry and fairly sunny area, on residual red soil of calcareous origin. The specimens probably originated from seeds produced by a tree cultivated in the neighboring garden.

N. Olivieri

\section{Platycladus orientalis (L.) Franco (Cupressaceae)}

+ (CAS) PUG: Castrignano del Capo (Lecce), loc. Santa Maria di Leuca, parete rocciosa lungo la Strada Provinciale 358 "Delle Terme Salentine" nei pressi dello svincolo per

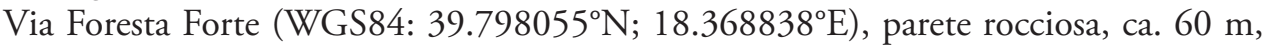
S, 21 August 2016, N. Olivieri (FI). - Casual alien species new for the flora of Puglia.

Some young individuals of the species have developed towards the top of the subvertical limestone rockface along the trench roadway, with Thymbra capitata (L.) Cav., Dittrichia viscosa (L.) Greuter subsp. viscosa and young individuals of Pistacia lentiscus L. They originated from seeds produced by some plants cultivated for ornamental purposes at the edges of a neighbouring private garden.

N. Olivieri

Pleuropterus multiflorus (Thunb.) Nakai (Polygonaceae)

三 Fallopia multiflora (Thunb.) Haraldson $\equiv$ Reynoutria multiflora (Thunb.) Moldenke 
+ (CAS) ABR: Teramo (Teramo), lungo l'alveo del Torrente Vezzola (WGS84: $42.664161^{\circ} \mathrm{N}$; $\left.13.699792^{\circ} \mathrm{E}\right)$, vegetazione ripariale, ca. $240 \mathrm{~m}, 16$ October 2016, $N$. Olivieri (FI). - Casual alien species new for the flora of Abruzzo.

Some individuals of the species grow along a path near the Vezzola Stream riverbed. They climb up to $3 \mathrm{~m}$ on Robinia pseudoacacia L. and Prunus cerasifera Ehrh. Below they are intertwined with branches of Rubus ulmifolius Schott. Pleuropterus multiflorus is a rhizomatous perennial climbing species, native to central and southern China ( $\mathrm{Li}$ et al. 2003), introduced in Europe probably in the late $19^{\text {th }}$ century as ornamental and recently spreading as alien in several administrative regions of northern Italy: Lombardia, Veneto, Trentino-Alto Adige, Piemonte (Galasso et al. 2006, Galasso and Ceffali 2008, Celesti-Grapow et al. 2009, Soldano and Galasso 2011), and EmiliaRomagna (http://www.actaplantarum.org/floraitaliae/viewtopic.php?f=40\&t=69727, http://www.actaplantarum.org/floraitaliae/viewtopic.php?f=40\&t=67829).

N. Olivieri

\section{Rumex cristatus DC. (Polygonaceae)}

+ (INV) BAS: Matera (Matera), Tre Ponti, Strada Provinciale Matera-Gioia del Colle (WGS84: $40.679146^{\circ} \mathrm{N} ; 16.627682^{\circ} \mathrm{E}$ ), margine stradale, con Avena sterilis subsp. ludoviciana, Dasypyrum villosum, Carduus pycnocephalus, Ferula communis, 342 m, 8 June 2016, N. Ardenghi, P. Cauzzi, F. Guzzon (Herb. N. Ardenghi); ibidem, Masseria di Pietrapenta, cava abbandonata (WGS84: $40.632286^{\circ} \mathrm{N} ; 16.543702^{\circ} \mathrm{E}$ ), terreno ruderale, con Beta maritima, Dittrichia viscosa, Foeniculum vulgare, 149 m, 9 June 2016, N. Ardenghi, P. Cauzzi (FI); ibidem, C.da Chiancalata, a lato della stradina per lo Studio legale Cifarelli (WGS84: $40.648249^{\circ} \mathrm{N} ; 16.609604^{\circ} \mathrm{E}$ ), fosso a lato della strada, con Avena sterilis e Sorghum halepense, 306 m, 10 June 2016, N. Ardenghi, P. Cauzzi, F. Guzzon (FI). - Invasive cryptogenic species new for the flora of Basilicata.

The choice of the invasive status is justified by the population near locality Tre Ponti in Matera, consisting of about 1,000 individuals distributed along the banks of the Fiumicello Stream over a distance of $1.15 \mathrm{~km}$, from Tre Ponti eastwards to the point where the streamflow changes its direction northwards (WGS84: $40.679487^{\circ} \mathrm{N} ; 16.641782^{\circ} \mathrm{E}$ ).

N.M.G. Ardenghi, P. Cauzzi, F. Guzzon

\section{Salvia abrotanoides (Kar.) Sytsma $\times$ Salvia yangii B.T.Drew (Lamiaceae)}

+ (CAS) ITALIA (LOM): Milano (Milano), binari a lato di Via Molinetto di Lorenteggio (comune di Corsico), angolo Via F. Gonin (WGS84: 45.441001 N; $9.117402^{\circ} \mathrm{E}$ ), binari del tram, 118 m, no exp., 29 September 2013, G. Galasso (FI, MSNM). Casual alien hybrid new for the flora of Italy (Lombardia). 
+ (CAS) TAA: Pergine Valsugana (Trento), Pergine, sull'argine destro del Torrente Fersina poco a valle del ponte per Brazzaniga (CFCE: 9933/1) (WGS84: $46.071290^{\circ} \mathrm{N}$; $\left.11.236011^{\circ} \mathrm{E}\right)$, argine-margine della strada, tre cespi in un punto dove certamente non è stata piantata, presenza casuale, $488 \mathrm{~m}, 30$ September 2014, A. Bertolli, F. Prosser, G. Tomasi (FI, ROV-67688). - Casual alien hybrid new for the flora of Trentino-Alto Adige.

+ (CAS) TOS: Siena (Siena), Strada di Marciano, su un muro esterno del Park Hotel

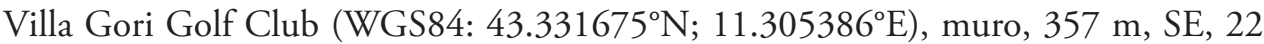
July 2016, G. Bonari (FI). - Casual alien hybrid new for the flora of Toscana.

Salvia subg. Perovskia (Kar.) J.B.Walker, B.T.Drew \& J.G.González (Drew et al. 2017) includes about 8 species widely distributed over arid regions of Asia (Krüssmann et al. 1986, Hedge 1990, Li and Hedge 1994, Grant 2000, Hedge 2011). We considered several sources to identify our plants. Several cultivars are selected by gardeners (Grant 2007) thereby complicating nomenclature and identification. At first glance, we were inclined to attribute the taxon to S. yangii (三 Perovskia atriplicifolia Benth.), but leaves were not "simple, margins crenate, serrate or subentire" as reported by Hedge (2011, see also Rechinger 1982). In fact, several varieties can be identified based on leaf shape and indumentum characters, but a comprehensive review is lacking (Hedge and Lamond 1968). Thus, "leaves bipinnatisect" guided us towards S. abrotanoides (三P. abrotanoides Kar.), also considering the figures (plates 369-372, 592) reported by Rechinger et al. (1982). However, this taxon did not perfectly fit our specimens either. Rechinger (1982) reported a hybrid (pl. 373 in Rechinger et al. 1982), which is the plant cultivated in North America according to Darke and Tucker (1989). Our plants seemed to correspond to "Perovskia $\times$ 'Hybrida' (= P. abrotanoides $\times$ atriplicifolia?)", based on the figure provided by Krüssmann et al. (1986), a plant cultivated by Hillier (England) since 1937 and distributed from the Geisenheim Research Institute since 1955 as $P$. 'Superba'. Because our specimens surely derived from seeds dispersed from cultivated flowerbeds in the cities, "P. "Hybrida"' should be the best name to apply, but "it is not clear whether the majority of cultivars are variants of $P$. atriplicifolia or hybrids between P. abrotanoides and P. atriplicifolia" (Grant 2007). Considering that they differ from both the genuine putative parental species, we prefer to use the name $S$. abrotanoides $\times S$. yangii, a hybrid apparently without nothospecific epithet because the only available one (in Perovskia) is $P$. xintermedia Lazkov (P. abrotanoides $\times P$. angustifolia Kudr.; Sennikov et al. 2011).

G. Bonari, G. Galasso, F. Prosser

\section{Senecio inaequidens DC. (Asteraceae)}

+ (NAT) PUG: San Giovanni Rotondo (Foggia), periferia S del paese (WGS84: $41.699155^{\circ} \mathrm{N} ; 15.720507^{\circ} \mathrm{E}$ ), margine stradale, $550 \mathrm{~m}, 25$ October 2016, R.P. Wagensommer (Herb. R.P. Wagensommer); ibidem, periferia SSW del paese (WGS84: 
$41.699451^{\circ} \mathrm{N} ; 15.711909^{\circ} \mathrm{E}$ ), margine stradale e su materiale di riporto (ghiaia), 560 m, 27 October 2016, R.P. Wagensommer (FI, Herb. R.P. Wagensommer); Lesina (Foggia), alla stazione ferroviaria (WGS84: $41.854374^{\circ} \mathrm{N} ; 15.296612^{\circ} \mathrm{E}$ ), margine stradale e del parcheggio asfaltato, $40 \mathrm{~m}, 27$ October 2016, R.P. Wagensommer (Herb. R.P. Wagensommer). - Naturalized alien species new for the flora of Puglia.

This invasive species occurs in all Italian administrative regions. To date, it was not recorded only in Puglia (Conti et al. 2005, Celesti-Grapow et al. 2009). We found it in two different sites on the Gargano Promontory, Lesina (about 30 mature individuals) and San Giovanni Rotondo (about 50 mature individuals).

R.P. Wagensommer, E.V. Perrino, G. Russo

\section{Setaria parviflora (Poir.) Kerguélen (Poaceae)}

+ (NAT) CAL: Scalea (Cosenza), Via Ruggiero di Lauria (WGS84: $39.815817^{\circ} \mathrm{N}$; $15.787228^{\circ} \mathrm{E}$ ), fessure della pavimentazione, $6 \mathrm{~m}, 20$ August 2014, A. Stinca (PORUN). - Status change from casual to naturalized alien for the flora of Calabria.

This species is recorded from Lombardia, Liguria, Toscana, Marche, Lazio, Campania, Puglia, Calabria, Sicilia, and Sardegna (Celesti-Grapow et al. 2009, Cecchi and Arrigoni 2013, Stinca et al. 2013, Gubellini et al. 2014, Stinca et al. 2016). In Calabria, Setaria parviflora is reported as a casual alien (Bernardo et al. 2009) where it was known only for the valley of the Crati River (Banfi and Passalacqua 2011). At Scalea, it exhibits a notable vegetative and sexual propagation capacity; it was also observed in August 2016.

A. Stinca

\section{Syagrus romanzoffiana (Cham.) Glassman (Arecaceae)}

+ (CAS) ITALIA (PUG): Brindisi (Brindisi), Via Duca degli Abruzzi, giardini pubblici presso il monumento al Marinaio d'Italia (WGS84: $40.644977^{\circ} \mathrm{N} ; 17.946627^{\circ} \mathrm{E}$ ), tappeto erboso umido spesso irrigato, ca. $10 \mathrm{~m}, \mathrm{~S}, 22$ August 2016, N. Olivieri (FI). Casual alien species new for the flora of Italy (Puglia).

Some very young specimens, identified according to Cullen et al. (2011) and Squire (2007), have grown close to adult individuals of the species in a wet meadow frequently watered and located near the Adriatic Sea. In Brindisi Syagrus romanzoffiana is very popular as an ornamental plant in gardens and avenues. Fruits are regularly produced and accumulate on the ground below the trees. The species is native to South America (Brazil, part of Argentina, Paraguay, Uruguay and Bolivia). For its ornamental value, it is widespread in many tropical and subtropical areas and, more recently, also in Mediterranean countries. It is naturalized in Florida, Mauritius and eastern 
Australia (Queensland and New South Wales), where it is considered an invasive alien (Randall 2001).

N. Olivieri

\section{Tradescantia fluminensis Vell. (Commelinaceae)}

+ (CAS) MOL: Termoli (Campobasso), versante collinare S del Vallone del Riovivo (WGS84: $41.993833^{\circ} \mathrm{N} ; 14.996083^{\circ} \mathrm{E}$ ), margine di sentiero e canneto di Arundo donax, ca. 27 m, 3 September 2016, N. Olivieri (FI). - Casual alien species new for the flora of Molise.

The species grows near the Adriatic coast, in the urban park of Termoli, along a path edge and inside a cane thicket of Arundo donax L., along with Rubus ulmifolius Schott, Hedera helix L. and Parietaria judaica L. Plants grow in penumbra, on sandstone soil covered by nitrophilous vegetation typical of disturbed shaded areas.

N. Olivieri

\section{Trifolium alexandrinum L. (Fabaceae)}

+ (CAS) BAS: Matera (Matera), Bosco di Lucignano, ca. $185 \mathrm{~m}$ a SE dalla Cisterna di San Francesco (WGS84: $40.606911^{\circ} \mathrm{N} ; 16.703098^{\circ} \mathrm{E}$ ), campo di grano duro, con Avena sterilis subsp. ludoviciana, Glebionis segetum, Anchusa azurea, Phalaris brachystachys, un esemplare, 363 m, 9 June 2016, N. Ardenghi, P. Cauzzi (FI). - Casual cryptogenic species new for the flora of Basilicata.

A single individual was found in the middle of a durum wheat field.

N.M.G. Ardenghi, P. Cauzzi, F. Guzzon

Vicia lens (L.) Coss. \& Germ. subsp. orientalis (Boiss.) Galasso, Banfi, Bartolucci \& J.-M.Tison, comb. nov. (Fabaceae)

urn:lsid:ipni.org:names:60474540-2

E Ervum orientale Boiss., Diagn. Pl. Orient., ser. 1 9: 115(-116). 1849 [I-II.1849] 三Lens orientalis (Boiss.) Schmalh., Fl. Sredn. Yuzhn. Rossii 1: 297. 1895 三Vicia orientalis (Boiss.) Bég. \& Diratz., Contr. Fl. Armenia: 61. 1912 [XI.1912] (n.v.) 三 Lens culinaris Medik. subsp. orientalis (Boiss.) Ponert, Feddes Repert. 83(9-10) (1972): 634. 1973 [25.IV.1973].

According to the molecular phylogenetic research published by Schaefer et al. (2012), the genus Lens Mill. is nested within Vicia L. For the type species of Lens 
(Lens culinaris Medik.), the binomial Vicia lens (L.) Coss. \& Germ. was restored by the above cited authors. Since the subspecific rank is considered suitable for representing taxonomic relationships between a domesticated crop and its wild relative, a new combination is proposed here for the wild relative of Vicia lens. It is distinct from the crop for a smaller size of the plant, allogamy, ready opening of the mature pod and seed dormancy (Ladizinski 1993, Zohari et al. 2012).

G. Galasso, E. Banfi, F. Bartolucci, J.-M. Tison

\section{Yucca gloriosa L. (Asparagaceae)}

+ (INV) TOS. - Status change from naturalized to invasive alien for the flora of Toscana.

Yucca gloriosa, native to North America, is currently recognized as naturalized in Toscana (Ciccarelli et al. 2015). During field surveys conducted along the coastal part of the Migliarino-San Rossore-Massaciuccoli Regional Park, we noted a widespread diffusion of the species. Its high frequency along the Tuscan coast can be also deduced from several floristic records (Peruzzi and Bedini 2015 onwards, Roma-Marzio et al. 2016 and literature cited therein). Based on our field observations, the species shows a high clonal propagation capacity, determining modifications in vegetation and ecosystem dynamics. In addition, the ad hoc LIFE project DUNETOSCA (http:// ec.europa.eu/environment/life/project/Projects/), conducted in 2010-2013, failed to eradicate the species. Based on these considerations, we regard the status of invasive alien to be most appropriate for $Y$. gloriosa in Toscana.

\section{D’Antraccoli, F. Roma-Marzio}

\section{References}

Ariello G (1952) Ancora una nuova avventizia per la flora piemontese: Paspalum distichum L. var. paspalodes Thell. e notizie sulla sua diffusione e di quella di Paspalum dilatatum Poir. Nuovo Giornale Botanico Italiano, n.ser. 58(3-4)[1951]: 622-625.

Azzella MM, Iberite M (2010) Notula: 40. In: Nepi C, Peccenini S, Peruzzi L (Eds) Notulae alla flora esotica d'Italia: 3(38-53). Informatore Botanico Italiano 42(2): 533.

Ballelli S (2002) Flora. In: Ballelli S, Castagnari G, Catorci A, Fortunati G (Eds) Aspetti geobotanici e lineamenti storico-ambientali dell'Alto Esino. Appennino umbro-marchigiano. Provincia di Ancona, Assessorato alla Tutela dell'Ambiente, Ancona, 29-175.

Banfi E, Galasso G (Eds) (2010) La flora esotica lombarda. Museo di Storia Naturale di Milano, Milano, 274 pp. [+ CD-Rom]

Banfi E, Galasso G (2015) Paspalum (Poaceae), aggiornamento per la flora italiana. In: Peruzzi L, Domina G (Eds) Approfondimenti floristici e sistematici sulla flora d'Italia. Dedicato a Edda Lattanzi in occasione dei suoi 85 anni. Comunicazioni. Orto botanico di Roma, La 
Sapienza Università di Roma, 20-21 novembre 2015. Società Botanica Italiana, Gruppo per la Floristica, Sistematica ed Evoluzione, Firenze, 41-42.

Banfi E, Passalacqua NG (2011) Setaria P. Beauv. In: Bernardo L, Peruzzi L, Passalacqua NG (Eds) Flora vascolare della Calabria - Prodromo. Volume I. Informatore Botanico Italiano 43(2): 298.

Barnes PG, Whiteley AC (2011) Elaeagnus Linnaeus. In: Cullen J, Knees SG, Cubey HS (Eds) The European Garden Flora. A manual for the identification of plants cultivated in Europe, both out-of-doors and under glass. 2 ed., Vol. 4. Cambridge University Press, Cambridge, 97-99.

Benson L (1982) The Cacti of the United States and Canada. Stanford University Press, Stanford. Bernardo L, Gangale C, Passalacqua NG, Uzunov D (2009) Regional Experts: Calabria. In: Celesti-Grapow L, Pretto F, Brundu G, Carli E, Blasi C (Eds) A thematic contribution to the National Biodiversity Strategy. Plant invasion in Italy, an overview. Ministry for the Environment Land and Sea Protection, Nature Protection Directorate, Rome, 32 pp. [+CD-Rom]

Bouvet D, Montacchini F, Siniscalco C (2005) Piemonte. In: Conti F, Abbate G, Alessandrini A, Blasi C (Eds) An annotated checklist of the Italian vascular flora. Palombi Editori, Roma, 33-185 + 255-259.

Bracchi G, Romani E (2010) Checklist aggiornata e commentata della flora vascolare della Provincia di Piacenza. Società Piacentina di Scienze Naturali e Museo Civico di Storia Naturale di Piacenza, Piacenza.

Buono V, Manni QG, Barone R, Campagna P, Civita F, Mauri ES, Pasquali G, Rignanese L, Stone AM, Sturloni S, Taneburgo G (2017) Rassegna di segnalazioni notevoli riguardanti la Puglia comparse nel forum Acta Plantarum. Acta Plantarum Notes 5: 61-67.

Cecchi L, Arrigoni PV (2013) Notula: 183. In: Barberis G, Nepi C, Peccenini S, Peruzzi L (Eds) Notulae alla flora esotica d'Italia: 8 (161-184). Informatore Botanico Italiano 45(1): 109.

Celesti-Grapow L, Pretto F, Brundu G, Carli E, Blasi C (Eds) (2009) A thematic contribution to the National Biodiversity Strategy. Plant invasion in Italy, an overview. Ministry for the Environment Land and Sea Protection, Nature Protection Directorate, Rome, 32 pp. [+CD-Rom]

Celesti-Grapow L, Capotorti G, Del Vico E, Lattanzi E, Tilia A, Blasi C (2013) The vascular flora of Rome. Plant Biosystems 147(4): 1059-1087. https://doi.org/10.1080/11263504. 2013.862315

Ceschin S, Salerno G, Bisceglie S, Kumbaric A (2010) Temporal floristic variation as indicator of environmental changes in the Tiber River in Rome. Aquatic Ecology 44(1): 93-100. https://doi.org/10.1007/s10452-009-9292-1

Ciccarelli D, Di Bugno C, Peruzzi L (2015) Checklist della flora vascolare psammofila della Toscana. Atti della Società Toscana di Scienze Naturali, Memorie, Serie B 121[2014]: 37-88.

Conti F, Abbate G, Alessandrini A, Blasi C (Eds) (2005) An annotated checklist of the Italian vascular flora. Palombi Editori, Roma.

Conti F, Alessandrini A, Bacchetta G, Banfi E, Barberis G, Bartolucci F, Bernardo L, Bonacquisti S, Bouvet D, Bovio M, Brusa G, Del Guacchio E, Foggi B, Frattini S, Galasso G, Gallo L, Gangale C, Gottschlich G, Grünanger P, Gubellini L, Iiriti G, Lucarini D, Marchetti D, 
Moraldo B, Peruzzi L, Poldini L, Prosser F, Raffaelli M, Santangelo A, Scassellati E, Scortegagna S, Selvi F, Soldano A, Tinti D, Ubaldi D, Uzunov D, Vidali M (2007) Integrazioni alla checklist della flora vascolare italiana. Natura Vicentina 10[2006]: 5-74.

Cullen J, Knees SG, Cubey HS (2011) Palmae (Arecaceae). In: Cullen J, Knees SG, Cubey HS (Eds) The European Garden Flora. A manual for the identification of plants cultivated in Europe, both out-of-doors and under glass. 2 ed., Vol. 1. Cambridge University Press, Cambridge, 361-372.

Darke FP, Tucker AO (1989) Identification of the Perovskia Species (Lamiaceae) Cultivated in North America. Baileya 23(1): 54.

Domina G, Mazzola P (2002) Note su alcune xenofite nuove o in espansione in Sicilia. Naturalista Siciliano, ser. 4 26(3-4): 165-174.

Drew BT, González-Gallegos JG, Xiang CL, Kriebel R, Drummond CP, Walker JB, Sytsma KJ (2017) Salvia united: The greatest good for the greatest number. Taxon 66(1): 133-145. https://doi.org/10.12705/661.7

Dufour-Dror J-M (Ed) (2013) Israel's Least Wanted Alien Ornamental Plant Species. Ornamental Plants Potentially Invasive in Israel's Natural Ecosystems. Israel Ministry of Environmental Protection, Israel Ministry of Agriculture, Nature and Parks Authority, Hebrew University Botanical Gardens. http://www.sviva.gov.il/English/env_topics/biodiversity/ Documents/InvasiveSpecies-July2013.pdf [accessed 30.03.2017]

Foggi B, Raffaelli M, Viciani D (2005) Toscana. In: Conti F, Abbate G, Alessandrini A, Blasi C (Eds) An annotated checklist of the Italian vascular flora. Palombi Editori, Roma, 33-185, 283-288.

Galasso G (2007) Notulae: 1328-1330. In: Conti F, Nepi C, Peruzzi L, Scoppola A (Eds) Notulae alla checklist della flora vascolare italiana: 4 (1311-1419). Informatore Botanico Italiano 39(2): 406-408.

Galasso G, Ceffali G (2008) Segnalazioni floristiche per il territorio bresciano. Natura Bresciana 35[2007]: 201.

Galasso G, Ceffali G, Colatore A (2006) Notula: 1249. In: Conti F, Nepi C, Scoppola A (Eds) Notulae alla checklist della flora vascolare italiana: 2 (1192-1266). Informatore Botanico Italiano 38(1): 208.

Galasso G, Domina G, Adorni M, Ardenghi NMG, Banfi E, Bedini G, Bertolli A, Brundu G, Calbi M, Cecchi L, Cibei C, D’Antraccoli M, De Bastiani A, Faggi G, Ghillani L, Iberite M, Latini M, Lazzeri V, Liguori P, Marhold K, Masin R, Mauri S, Mereu G, Nicolella G, Olivieri N, Peccenini S, Perrino EV, Peruzzi L, Petraglia A, Pierini B, Prosser F, RomaMarzio F, Romani E, Sammartino F, Selvaggi A, Signorile G, Stinca A, Verloove F, Nepi C (2016a) Notulae to the Italian alien vascular flora: 1. Italian Botanist 1: 17-37. https://doi. org/10.3897/italianbotanist.1.8777

Galasso G, Domina G, Ardenghi NMG, Arrigoni P, Banfi E, Bartolucci F, Bonari G, Buccomino G, Ciaschetti G, Conti F, Coppi A, Di Cecco V, Di Martino L, Guiggi A, Lastrucci L, Leporatti ML, López Tirado J, Maiorca G, Mossini S, Olivieri N, Pennesi R, Romiti B, Scoppola A, Soldano A, Stinca A, Verloove F, Villa M, Nepi C (2016b) Notulae to the Italian alien vascular flora: 2. Italian Botanist 2: 55-71. https://doi.org/10.3897/italianbotanist. 2.11144 
Grant ML (2000) Perovskia Karelin. In: Cullen J, Alexander JCM, Brickell CD, Edmondson JR, Green PS, Heywood VH, Jörgensen P-M, Jury SL, Knees SG, Maxwell HS, Miller DM, Robson NKB, Walters SM, Yeo PF (Eds) The European Garden Flora. A manual for the identification of plants cultivated in Europe, both out-of-doors and under glass, Vol. 6. Cambridge University Press, Cambridge, 205-206.

Grant M (2007) Perovskia. RHS Plant Trials and Assessments 3: 1-5.

Gubellini L (2005) Marche. In: Conti F, Abbate G, Alessandrini A, Blasi C (Eds) An annotated checklist of the Italian vascular flora. Palombi Editori, Roma, 33-185, 243-246.

Gubellini L (2009) Regional Experts: Marche. In: Celesti-Grapow L, Pretto F, Brundu G, Carli E, Blasi C (Eds) A thematic contribution to the National Biodiversity Strategy. Plant invasion in Italy, an overview. Ministry for the Environment Land and Sea Protection, Nature Protection Directorate, Rome, 32 pp. [+CD-Rom]

Gubellini L, Hofmann N, Pinzi M (2014) Contributo alla conoscenza della flora vascolare delle Marche e di alcune regioni limitrofe. Informatore Botanico Italiano 46(1): 17-26.

Hedge IC (1990) Labiatae. In: Ali SI, Nassir YJ (Eds) Flora of Pakistan, Vol. 192. Royal Botanic Garden, Edinburgh, 1-310.

Hedge IC (2011) Perovskia Kar. In: Flora of Pakistan. Tropicos.org, Missouri Botanical Garden, Saint Louis. http://www.tropicos.org/Name/40004933?projectid=32 [accessed 19.12.2016]

Hedge IC, Lamond JM (1968) Studies in the flora of Afghanistan: VII. Labiatae: Lam.-end. Notes from the Royal Botanic Garden of Edinburgh 28: 89-191.

Iamonico D (2015) Taxonomic revision of the genus Amaranthus (Amaranthaceae) in Italy. Phytotaxa 199(1): 1-84. https://doi.org/10.11646/phytotaxa.199.1.1

Iberite M, Pierfranceschi M, Abbate G (2010) L'Erbario Anzalone: riordino e catalogazione informatizzata. Annali di Botanica, n.ser. suppl. 2009: 79-84.

Johnson GP (1997) Calycanthaceae Lindley. In: Flora of North America Editorial Committee, Flora of North America, Vol. 3. Oxford University Press, New York, Oxford, 23-25.

Krüssmann G, Epp ME, Daniels GS (1986) Manual of cultivated broad-leaved trees \& shrubs. Translated and revised from the German: Krüssmann, Handbuch der Laubgehölze, 1977 by Verlag Paul Parey, Berlin and Hamburg, Vol. 2. BT Batsford Ltd, London.

Ladizinski G (1993) Lentil Domestication: On the Quality of Evidence and Arguments. Economic Botany 47(1): 60-64. https://doi.org/10.1007/BF02862206

Lazzari G, Merloni N, Saiani D (2010) Flora delle Pinete storiche di Ravenna - San Vitale, Classe, Cervia. Parco Delta del Po. Quaderni dell'Ibis 4: 1-64.

Lazzari G, Merloni N, Saiani D (2012) Siti della Rete Natura 2000 della fascia costiera ravennate. Parco Delta del Po - Emilia-Romagna. Quaderni dell'Ibis 6: 1-80.

Lazzeri V, Sammartino F, Campus G, Caredda A, Mascia F, Mazzoncini V, Testa N, Gestri G (2015) Note floristiche tosco-sarde II: novità regionali e locali e considerazioni tassonomiche per le regioni Sardegna e Toscana. Annali del Museo Civico di Rovereto. Sezione: Archeologia, Storia, Scienze Natutali 30[2014]: 331-368.

Li A-J, Bojian B, Grabovskaya-Borodina AE, Hong S-P, McNeill J, Mosyakin SL, Ohba H, Park C-w (2003) Polygonaceae. In: Wu ZY, Raven PH, Hong DY (Eds) Flora of China, Vol. 5. Science Press, Beijing, Missouri Botanical Garden Press, St. Louis, 277-350. 
Li H-W, Hedge IC (1994) Lamiaceae. In: Wu ZY, Raven PH (Eds) Flora of China, Vol. 17. Science Press, Beijing, Missouri Botanical Garden Press, Saint Louis, 50-299.

Martini F, Scholz H (1998) Eragrostis virescens J.Presl (Poaceae), a new alien species for the Italian flora. Willdenowia 28(1-2): 59-63. https://doi.org/10.3372/wi.28.2805

Mauri S, Galasso G, Banfi E (2012) Notula: 144. In: Barberis G, Nepi C, Peccenini S, Peruzzi L (Eds) Notulae alla flora esotica d'Italia: 7 (136-160). Informatore Botanico Italiano 44(2): 400-401.

Peruzzi L, Bedini G (Eds) (2015 onwards) Wikiplantbase \#Toscana v2.1. Università di Pisa. http://bot.biologia.unipi.it/wpb/toscana/index.html [accessed 15.03.2017]

Pierini B, Peruzzi L (2014) Prodromo della Flora Vascolare della Provincia di Lucca (Toscana nordoccidentale). Informatore Botanico Italiano 46(1): 3-16 + electronic appendix (500 pp.).

Podda L, Lazzeri V, Mascia F, Mayoral O, Bacchetta G (2012) The Checklist of the Sardinian Alien Flora: an Update. Notulae Botanicae Horti Agrobotanici Cluj-Napoca 40(2): 14-21.

Randall R (2001) Garden thugs, a national list of invasive and potentially invasive garden plants. Plant Protection Quarterly 16(4): 138-171.

Rechinger KH (1982) Perovskia. In: Rechinger KH, Hedge IC, Ietswaart JH, Jalas J, Mennema J, Seybold S (Eds) Flora Iranica, Vol. 150. Akademische Druck- u. Verlagsanstalt, Graz, 476-479.

Rechinger KH, Hedge IC, Ietswaart JH, Jalas J, Mennema J, Seybold S (1982) Flora Iranica, Vol. 150 (Tabulae). Akademische Druck- u. Verlagsanstalt, Graz.

Ricciardi M, Aprile GG, La Valva V, Caputo G (1988) La flora del Somma-Vesuvio. Bollettino della Società dei Naturalisti di Napoli 96: 3-121.

Roma-Marzio F, Bedini G, Müller J, Peruzzi L (2016) A critical checklist of the woody flora of Tuscany (Italy). Phytotaxa 287(1): 1-135. https://doi.org/10.11646/phytotaxa.287.1.1

Rosati L, Salerno G, Del Vico E, Lapenna MR, Villani MC, Filesi L, Fascetti S, Lattanzi E (2012) Un aggiornamento alla flora del Cilento e della Campania. Informatore Botanico Italiano 44(1): 111-119.

Sanders RW (2012) Taxonomy of Lantana sect. Lantana (Verbenaceae): II. Taxonomic revision. Journal of the Botanical Research Institute of Texas 6(2): 403-441.

Schaefer H, Hechenleitner P, Santos-Guerra A, Menezes de Sequeira M, Pennington RT, Kenicer G, Carine MA (2012) Systematics, biogeography, and character evolution of the legume tribe Fabeae with special focus on the middle-Atlantic island lineages. BioMed Central Evolutionary Biology 12: 250. https://doi.org/10.1186/1471-2148-12-250

Schicchi R (1999) Spontaneizzazione di Ficus microcarpa L. (Moraceae) e Cardiospermum grandiflorum Sw. (Sapindaceae) in Sicilia. Naturalista Siciliano, ser. 4 23(1-2): 315-317.

Sennikov AN, Lazkov GA, Uotila P, Weber HE (2011) Taxonomic corrections and new records in vascular plants of Kyrgyzstan. Memoranda Societatis pro Fauna et Flora Fennica 87: 41-64.

Soldano A, Galasso G (2011) Notula: 109. In: Barberis G, Nepi C, Peccenini S, Peruzzi L (Eds) Notulae alla flora esotica d'Italia: 5(94-114). Informatore Botanico Italiano 43(2): 376.

Squire D (2007) Palms and Cycads. A complete guide to selecting, growing and propagating. New Holland Publishers, London. 
Stinca A, D’Auria G, Salerno G, Motti R (2013) Ulteriori integrazioni alla flora vascolare aliena della Campania (Sud Italia). Informatore Botanico Italiano 45(1): 71-81.

Stinca A, Croce A, D’Auria G, Salerno G, Santangelo A, Rosati L, Motti R (2016) Nuovi dati sulla flora vascolare aliena della Campania (Sud Italia). Atti della Società Toscana di Scienze Naturali, Memorie, Serie B, 122[2015]: 89-110.

Valdés B, Scholz H; with contributions from Raab-Straube E von, Parolly G (2009) Poaceae (pro parte majore). Euro+Med Plantbase - the information resource for Euro-Mediterranean plant diversity. http://www.emplantbase.org/home.html [accessed 28.09.2016]

Verloove F, Brusa G, Ardenghi NMG (2016) Studies in the genus Paspalum (Paniceae, Poaceae) in Europe: 3. Paspalum thunbergii, a new naturalized neophyte in W Europe. Willdenowia 46(1): 137-143. https://doi.org/10.3372/wi.46.46111

Zhou Z, Gilbert MG (2003) Moraceae. In: Wu ZY, Raven PH, Hong DY (Eds) Flora of China, Vol. 5. Science Press, Beijing, Missouri Botanical Garden Press, St. Louis, 21-73.

Zohari D, Hopf M, Weiss E (2012) Domestication of Plants in the Old World (4 $4^{\text {th }}$ edn). Oxford University Press, Oxford. https://doi.org/10.1093/acprof:osobl/9780199549061.001.0001 